Tropical Journal of Pharmaceutical Research March 2021; 20 (3): 599-604

ISSN: $1596-5996$ (print); 1596-9827 (electronic)

(C) Pharmacotherapy Group, Faculty of Pharmacy, University of Benin, Benin City, 300001 Nigeria.

\title{
Molecular modelling studies and synthesis of novel quinoxaline derivatives with potential inhibitory effect on GSK-3 $\beta$
}

\author{
Lubna Swellmeen ${ }^{1 *}$, Amal Uzrail ${ }^{2}$, Rand Shaheen ${ }^{3}$, Yusuf AL-Hiari4 \\ ${ }^{1}$ Department of Pharmaceutical Sciences, Faculty of Pharmacy, Zarqa University, ${ }^{2}$ Department of Medical Analysis, Faculty of \\ Sciences, Al-Albayt University, ${ }^{3}$ Department of Pharmaceutical Chemistry, Faculty of Pharmaceutical Sciences, Hashemite \\ University, ${ }^{4}$ Faculty of Pharmacy, The University of Jordan, Amman, Jordan
}

*For correspondence: Email: Iswellmeen@zu.edu.jo; Tel: +962 778004500

Sent for review: 26 July 2020

Revised accepted: 16 February 2021

\begin{abstract}
Purpose: To synthesize quinoxaline derivatives and investigate their inhibitory effects on glycogen

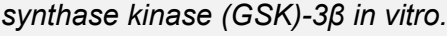

Methods: Quinoxaline derivatives were synthesized via reaction between synthon 1 and DL- 2-amino succinic acid, and subsequent lactamization reaction. The new compounds were tested against GSK-3 $\beta$ in vitro to select the most potent compound which was then used for molecular modelling.

Results: Novel quinoxaline derivatives with quinolone nucleus were successfully synthesized via simple

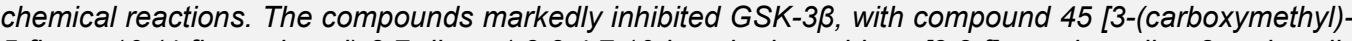
5-fluoro-10-(4-fluorophenyl)-2, 7-dioxo-1,2,3,4,7,10-hexahydropyrido [2,3-f] quinoxaline-8-carboxylic acid] achieving the best effect $\left(I C_{50}=0.18 \mu M\right)$. The half maximal inhibitory concentrations $\left(I C_{50}\right)$ of the compounds were in micromolar range. Molecular modelling revealed several interactions between

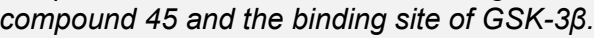

Conclusion: These results indicate that 3-(carboxymethyl)-5-fluoro-10-(4-fluorophenyl)-2,7-dioxo$1,2,3,4,7,10$-hexahydropyrido [2,3-f] quinoxaline-8-carboxylic acid is a potent inhibitor of GSK-3 $\beta$ and is thus a promising scaffold for the development of novel drugs that can effectively inhibit GSK-3 $\beta$ signaling pathway.
\end{abstract}

Keywords: Quinoxaline derivatives, Glycogen synthase kinase (GSK)-3ß, Molecular docking, Quinoline nucleus

\begin{abstract}
This is an Open Access article that uses a fund-ing model which does not charge readers or their institutions for access and distributed under the terms of the Creative Commons Attribution License (http://creativecommons.org/licenses/by/4.0) and the Budapest Open Access Initiative (http://www.budapestopenaccessinitiative.org/read), which permit unrestricted use, distribution, and reproduction in any medium, provided the original work is properly credited.
\end{abstract}

Tropical Journal of Pharmaceutical Research is indexed by Science Citation Index (SciSearch), Scopus, International Pharmaceutical Abstract, Chemical Abstracts, Embase, Index Copernicus, EBSCO, African Index Medicus, JournalSeek, Journal Citation Reports/Science Edition, Directory of Open Access Journals (DOAJ), African Journal Online, Bioline International, Open-J-Gate and Pharmacy Abstracts

\section{INTRODUCTION}

Glycogen synthase kinase 3 (GSK-3), a highly ubiquitous serine/threonine kinase, has two isoforms: GSK-3 $\alpha$ and GSK-3 $\beta$ [1]. Glycogen synthase is a key enzyme in biological processes such as apoptosis, intracellular communication, regulation of glucose metabolism and gene transcription [2]. The pathogeneses of type-2 diabetes mellitus (T2DM), Alzheimer's disease (AD) and some cancers are thought to involve GSK-3 $\beta$ signaling pathway [3-6]. Overexpression of GSK-3 $\beta$ has been implicated in pancreatic, breast, and skin cancers $[7,8]$. 
Molecular modelling is used to unravel binding interactions between newly synthesized compounds and potential target enzymes/proteins $[9,10]$. The technique has been successfully employed for the elucidation of the crystal lattice structure of GSK-3 $\beta$.

Heterocyclic compounds are a class of substances, which play critical roles in drug discovery through their incorporation into the structures of a large variety of drugs used for the treatment of diverse diseases. Quinoxaline is an important heterocyclic nucleus with a wide spectrum of biological activity. Quinoxaline scaffold possesses promising therapeutic properties such as anticancer, antimalarial, antiinflammatory, antimicrobial and anti-HIV effects [11]. It has been used as scaffold in drugs that function as protein kinase inhibitors [11]. Quinoline pharmacophore possesses antibacterial, anticancer and kinase inhibitory activities [12,13]. The aim of this study was to synthesize quinoxaline derivatives and investigate their inhibitory effects on GSK-3 $\beta$ in vitro.<smiles>C1=CNc2ccccc2C1</smiles>

A.

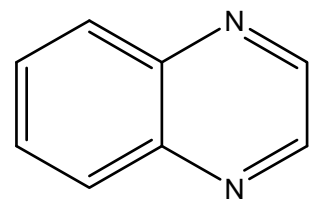

B.
Figure 1: Diagram of heterocyclic nucleus Quinoline nucleus; and (B): Quinoxaline nucleus

\section{EXPERIMENTAL}

\section{Chemicals and reagents}

All reagents and chemicals used in this study were of analytical grade, and they were products of Sigma-Aldrich (USA). Glycogen synthase kinase (GSK)-3 $\beta$ assay kit was obtained from Thermo Fisher Scientific Co. Ltd (USA).

\section{Technique}

Melting point (mp) was measured with Stuart scientific electrothermal heating apparatus (EA3000 A). Infra-red (IR) spectrum was recorded using Shimadzu FT-IR spectrophotometer (8400F). Proton and carbon nuclear magnetic resonance (NMR) spectra were analyzed with Bruker Avance spectrometer (DPX-300), while molecular mass was measured with high resolution mass spectrophotometer (Bruker APEX-4).
Synthesis of 7-chloro-1-alkyl-6-fluoro-8-nitro4-oxo-1,4-dihydroquinoline-3-carboxylic acid analogues

The synthons (a, b and $\mathbf{c})$ were synthesized via simple chemical reactions as previously described $[14,15]$.<smiles>[R]n1cc(C(=O)[O-])c(=O)c2cc(F)c(Cl)c([N+](=O)[O-])c21</smiles>

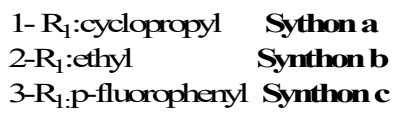

Figure 2: General formulae of synthons $a, b$ and c

\section{Synthesis of synthon I derivatives}

Synthon I was produced as a product of the reaction between the synthons $(\mathbf{a}, \mathbf{b}$ and $\mathbf{c})$ and DL- 2-amino succinic acid (Scheme 1) [ 13]. Exactly $3.2 \mathrm{~g}$ of DL- 2-amino succinic acid (24.0 $\mathrm{mmol}$ ) was mixed with $2.0 \mathrm{~g}$ of synthon $\mathbf{a}, \mathbf{b}$ or $\mathbf{c}$ in $65 \%$ ethanol $(250 \mathrm{~mL})$ under conditions illustrated in scheme 1. The mixing was done under reflux at $75-85{ }^{\circ} \mathrm{C}$, and $3.5 \mathrm{M} \mathrm{HCl}$ was used to adjust $\mathrm{pH}$ of the reaction mixture to 7 . The reaction lasted 10 days.

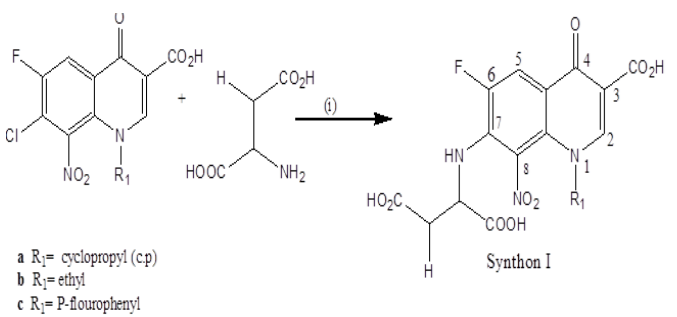

(1) $\mathrm{NaHCO}_{3}, 50-60 \%$ ethanol, $70-80^{\circ} \mathrm{C}$

Scheme 1: Synthesis of synthon I

\section{Synthesis of synthon II}

Exactly $6.0 \mathrm{~g}$ of sodium dithionite powder (43.5 $\mathrm{mmol}$ ) was dissolved in $0.33 \mathrm{~L}$ of distilled water and then gradually added to $1.0 \mathrm{~g}$ of synthon I for $45 \mathrm{~min}$ at room temperature (Scheme 2). Reduction of nitro group on position 8 in synthon I to amino group was done via addition of aqueous sodium dithionite in potassium carbonate. Spontaneous lactamization led to the 
formation of synthon II. The reductive cyclization process was fast and direct, lasting $60-120 \mathrm{~min}$. $[17,18]$.

Spectrum analysis was carried out to confirm that the synthesized compound was synthon II.

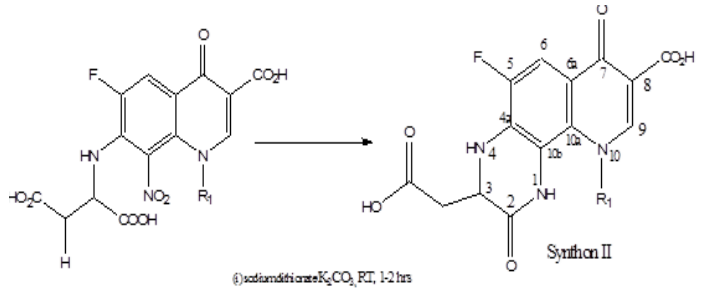

Scheme 2: Synthesis of synthon II

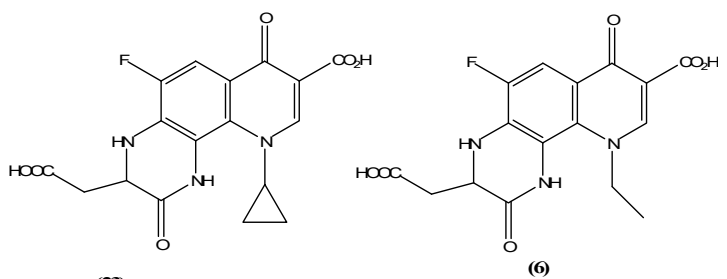

(23)

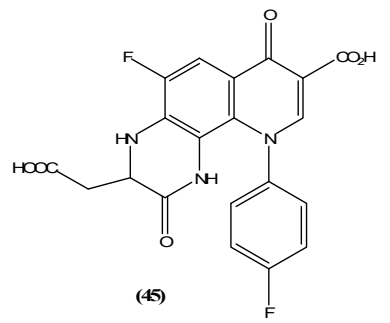

Figure 3: Chemical structures of synthesized compounds used as GSK-3 $\beta$ inhibitors (compounds 23, 6 and 45)

\section{Preparation of synthon II derivatives for in} vitro assay

Exactly $10 \mathrm{mg}$ of each synthon II derivative (compounds 6, 23 and 45) was dissolved in dimethyl sulfoxide (DMSO) to obtain stock solutions of required concentrations, which were sent to Thermo Fisher Scientific Co. Ltd. (USA) where activity of GSK-3 $\beta$ was assayed.

\section{Hits profiling against GSK-3 $\beta$}

To determine $I_{50}$ values of synthon II derivatives, inhibition of GSK-3 $\beta$ using Z'-LYTE GSK-3 $\beta$ assay was performed with varied concentrations of each compound (Z'-LYTETM Screening Protocol and Assay Conditions, 2016). The inhibition and concentration data were used to determine $\mathrm{IC}_{50}$ for each compound, and the most active compound was then selected. Solution of $10 \mathrm{mM}$ concentration of each synthetic compound $(6,23$ and 45$)$ was prepared in DMSO and sent for analysis at Thermo Fisher Scientific Co. Ltd. (USA) [16].

\section{Molecular modelling studies}

\section{Docking settings}

LibDock is a site-feature docking algorithm that docks ligands into active sites under guidance by binding hotspots. The most potent of synthesized quinoxaline derivatives (based on $\mathrm{IC}_{50}$ values) were docked into the binding pocket of GSK-3 $\beta$ (PDB code: 3Q3B; resolution of 2.7 Á) using LibDock (Discovery Studio version 4.5). Apart from ensuring the fitting of hypothesized molecule into the binding pocket, the procedure also aided the visualization of bonds formed between the compound and amino acids in the binding pocket of GSK-3 $\beta$. Molecular modelling provided clues to binding forces and inhibitory activity of the compound. The LibDock tool consisted of two major parts: allocation of binding site in the receptor, and running of docking procedure. Docking was performed via allocation of conformations of the ligand to polar receptor interaction sites and apolar ones (hotspots). A catalyst was added to ensure that conformations formed on the fly. CHARMM-based algorithm was used to analyze the interaction between the complexes formed.

\section{RESULTS}

\section{Properties of synthesized compounds}

Novel quinoxaline derivatives with quinolone nucleus were successfully synthesized via simple chemical reactions. The properties of the synthesized synthons are shown below:

\section{Synthon I}

\section{2-[(3-Carboxy-1-cyclopropyl-6-fluoro-8-nitro- 4-oxo-1,4-dihydroquinolin-7-yl) amino] succinic acid}

Bright yellow crystals: yield $=75 \% ; \mathrm{mp}=211-$ $214{ }^{\circ} \mathrm{C}$; ${ }^{1} \mathrm{H}-\mathrm{NMR}$ (300 MHz, DMSO- $\left.\mathrm{d}_{6}\right): \delta$ 0.85,1.15 (2 m, 4 H, H2-2'/H2-3'), 1.80 (2 H, CH $\mathrm{COOH}), 3.42\left(\mathrm{~m}, 1 \mathrm{H}, \mathrm{H}-1^{\prime}\right), 4.34(\mathrm{~d}, J=7.8 \mathrm{~Hz}$, $1 \mathrm{H}, \mathrm{CH}-\mathrm{NH}), 7.48$ (d, J = $11.7 \mathrm{~Hz}, 1 \mathrm{H}, \mathrm{H}-5)$, $8.39\left(\mathrm{~d},{ }^{3} \mathrm{~J}_{\mathrm{H}-\mathrm{F}}=5 \mathrm{~Hz}, 1 \mathrm{H}, \mathrm{NH}-\mathrm{CH}\right), 8.59(\mathrm{~s}, 1 \mathrm{H}$, $\mathrm{H}-2)$, 13.31 - 15.5 (br m, $\left.3 \mathrm{H}, 3 \mathrm{CO}_{2} \mathrm{H}\right) ;{ }^{13} \mathrm{C}-\mathrm{NMR}$ (300 MHz, DMSO- d6): $\delta 10.34$ (C-2'l C-3') , $37.19\left(\mathrm{CH}_{2}-\mathrm{CO}_{2} \mathrm{H}\right), 40.76\left(\mathrm{C}-1^{\prime}\right), 70.23(\mathrm{CH}-\mathrm{NH})$, 106.53 (C-3), 108.48 (C-5 ), 117.75 (C-4a), $129.65\left(\mathrm{~d},{ }^{3} J_{\mathrm{C}-\mathrm{F}}=5.1 \mathrm{~Hz}, \mathrm{C}-8\right), 137.07\left(\mathrm{~d},{ }^{2} \mathrm{~J}_{\mathrm{C}-\mathrm{F}}=\right.$ $14.25 \mathrm{~Hz}, \mathrm{C}-7), 148.43$ (C-2), 155.95 (C-6), $166.78\left(\mathrm{C}_{(3)}-\mathrm{CO}_{2} \mathrm{H}\right), 174.60(\mathrm{C}-4)$; IR $(\mathrm{NaCl}): \mathrm{v}$ 
3410, 2924, 2854, 2646, 2430, 2360, 2268, $2106,1982,1628,1296,1195,1072 \mathrm{~cm}^{-1}$.

2-[(3-carboxy-1-ethyl-6-fluoro-8-nitro-4-oxo1,4-dihydroquinolin-7-yl) amino] succinic acid

Yellow solid; yield $=75 \% ; m p=209-210{ }^{\circ} \mathrm{C}$ [13].

2-[(3-carboxy-1-(4-fluorophenyl)--6-fluoro-8nitro-4-oxo-1,4-dihydroquinolin-7-yl) amino] succinic acid

Yellow solid; yield $=1.5 \mathrm{~g}(82.5 \%) ; \mathrm{mp}=224-$ $225{ }^{\circ} \mathrm{C}$; ${ }^{1} \mathrm{H}-\mathrm{NMR}\left(300 \mathrm{MHz}, \mathrm{DMSO}-\mathrm{d}_{6}\right): \delta 2.88$ (d, $\left.J=17.1 \mathrm{~Hz}, 2 \mathrm{H}, \mathrm{CH}_{2}-\mathrm{COOH}\right), 4.80(\mathrm{~d}, J=$ $4.2 \mathrm{~Hz}, 1 \mathrm{H}, \mathrm{CH}-\mathrm{NH}), 7.15(\mathrm{~d}, \mathrm{~J}=8.4 \mathrm{~Hz}, 1 \mathrm{H}$, $\mathrm{NH}-\mathrm{CH}), 7.35\left(2 \mathrm{H}, \mathrm{H}-3^{\prime} / \mathrm{H}-5^{\prime}\right), 7.67$ (d, J = 19.5 $\mathrm{Hz}, 2 \mathrm{H}, \mathrm{H}-2^{\prime} / \mathrm{H}-6$ '), 8.14 (d, ${ }^{3} \mathrm{~J}_{\mathrm{H}-\mathrm{F}}=13.5 \mathrm{~Hz}, 1 \mathrm{H}$, $\mathrm{H}-5), 8.53$ (s, $1 \mathrm{H}, \mathrm{H}-2), 13.31-15.5$ (br m, $3 \mathrm{H}$, $\left.3 \mathrm{CO}_{2} \mathrm{H}\right) ; \mathrm{IR}(\mathrm{NaCl}): \mathrm{u} 3788,3417,2924,2854$, 2731, 2584, 2337, 2083, 1813, 1751, 1643, $1481,1381,1273,1195,1072 \mathrm{~cm}^{-1}$.

\section{Synthon II derivatives}

3-(carboxymethyl)-10-cyclopropyl-5-fluoro2,7-dioxo-1,2,3,4,7,10-hexahydropyrido [2,3f]quinoxaline-8-carboxylic acid (compound 23)

Faint yellow crystals; yield $=54 \% ; m p=285^{\circ} \mathrm{C}$; ${ }^{1} \mathrm{H}-\mathrm{NMR}\left(300 \mathrm{MHz}, \mathrm{DMSO}-\mathrm{d}_{6}\right)$ : $\delta 0.97-1.22$ (m, $\left.4 \mathrm{H}, \mathrm{H} 2-2^{\prime} / \mathrm{H} 2-3^{\prime}\right), 2.72(\mathrm{t}, \mathrm{J}=6.0 \mathrm{~Hz}, 2 \mathrm{H}$, $\left.\mathrm{CH}_{2}-\mathrm{CO}_{2} \mathrm{H}\right), 4.26\left(\mathrm{~m}, 1 \mathrm{H}, \mathrm{H}-1^{\prime}\right), 4.50(\mathrm{~s}, 1 \mathrm{H}, \mathrm{NH}-$ $\mathrm{C}(3)-\mathrm{H}), 7.34$ (d, $\left.{ }^{3} \mathrm{~J}_{\mathrm{H}-\mathrm{F}}=10.5 \mathrm{~Hz}, 1 \mathrm{H}, \mathrm{H}-6\right), 8.56$ (s, $1 \mathrm{H}, \mathrm{H}-9), 10.39$ (br s, $1 \mathrm{H}, \mathrm{N}(1)-\mathrm{H}), 12.28$ (br $\mathrm{s}, 1 \mathrm{H}, \mathrm{CH} 2-\mathrm{CO} 2 \mathrm{H}), 15.15$ (br s, $1 \mathrm{H}, \mathrm{CH} 2-$ $\mathrm{CO}_{2} \mathrm{H}$ ); ${ }^{13} \mathrm{C}-\mathrm{NMR}(300 \mathrm{MHz}$, DMSO- d6 ): $\delta 9.95$ $\left(\mathrm{C}-2^{\prime}\right), 10.60\left(\mathrm{C}-3^{\prime}\right), 35.34\left(\mathrm{CH}_{2}-\mathrm{CO}_{2} \mathrm{H}\right), 38.93(\mathrm{C}-$ 1'), 51.71 (CH-NH), 105.33 (d, C-6), 107.23 (C8), 116.06 (d, $\left.{ }^{3} \mathrm{~J}_{\mathrm{C}-\mathrm{F}}=6.3 \mathrm{~Hz}, \mathrm{C}-6 \mathrm{a}\right), 117.23$ (C10b), 129.29 (C-10a), 131.59 (C-4a), 150.2 (C6), 151.04 (C-9), $164.78\left(\mathrm{C}(8)-\mathrm{CO}_{2} \mathrm{H}\right), 166.14$ $\left(\mathrm{CH}_{2} \mathrm{CO}_{2} \mathrm{H}\right), \quad 171.75 \quad(\mathrm{C}-2), 176.77 \quad(\mathrm{C}-7) ; \quad$ IR $(\mathrm{NaCl}): \vee 3575,3550,3514,3000,2850,2375$, $2325,1730,1677,1334,1250,1030 \mathrm{~cm}^{-1}$.

3-(carboxymethyl)-10-ethyl-5-fluoro-2,7-dioxo1,2,3,4,7,10-hexahydropyrido[2,3-

f]quinoxaline-8-carboxylic acid (compound 6)

Yellow crystals: yield $=0.37 \mathrm{~g}(97 \%) ; \mathrm{mp}=299$ 301; ${ }^{1} \mathrm{HNMR}$ (300 MHz, DMSO- $\mathrm{d}_{6}$ ): $\delta 1.14$ (br t, $J=6.6 \mathrm{~Hz}, 3 \mathrm{H}, \mathrm{CH}_{2} \mathrm{CH}_{3}$ ), 2.92 (brs, $2 \mathrm{H}, \mathrm{CH}_{2-}$ $\left.\mathrm{CO}_{2} \mathrm{H}\right), 4.30(\mathrm{~m}, 1 \mathrm{H}, \mathrm{NH}-\mathrm{CH}-3), 4.80(\mathrm{~m}, 2 \mathrm{H}$, $\left.\mathrm{CH}_{2} \mathrm{CH}_{3}\right), 7.52$ ( $\left.\mathrm{NH}-4-\right), 7.73$ (d, ${ }^{3} J_{\mathrm{C}-\mathrm{F}}=10.5 \mathrm{~Hz}, 1$ $\mathrm{H}, \mathrm{H}-6), 8.86$ (s, $1 \mathrm{H}, \mathrm{H}-9$ ), 10.68 (br s, $1 \mathrm{H}, \mathrm{N}(1)-$
$\mathrm{H}), 12.51$ (br s, $1 \mathrm{H}, \mathrm{CH}_{2}-\mathrm{COOH}$ ), 15.25 (s, $1 \mathrm{H}$, $\mathrm{C}(8)-\mathrm{COOH}$ ), 14.7 (brs, $1 \mathrm{H}, \mathrm{C}-2 " \mathrm{COOH}$ ); ${ }^{13} \mathrm{C}-$ NMR (300 MHz, DMSO- $\left.\mathrm{d}_{6}\right)$ : $\delta 15.09\left(\mathrm{CH}_{3}\right)$, $34.95\left(\mathrm{CH}_{2}-\mathrm{CO}_{2} \mathrm{H}\right), 51.44\left(\mathrm{CH}_{2} \mathrm{CH}_{3}\right), 52.18(\mathrm{CH}-$ $\mathrm{NH}), 105.61\left(\mathrm{~d},{ }^{2} \mathrm{~J}_{\mathrm{C}-\mathrm{F}}=18.7 \mathrm{~Hz}, \mathrm{C}-6\right), 107.58(\mathrm{C}-$ 8), $116.36\left(\mathrm{~d},{ }^{3} \mathrm{~J}_{\mathrm{C}-\mathrm{F}}=6 \mathrm{~Hz}, \mathrm{C}-10 \mathrm{~b}\right), 118.16\left(\mathrm{~d},{ }^{3} \mathrm{~J}_{\mathrm{C}-}\right.$ $\mathrm{F}=7.5 \mathrm{~Hz}, \mathrm{C}-6 \mathrm{a}), 127.7$ (C-10a), 132.2 (C-4a), 149.45 (C-6), 150.94 (C-9), $165.36\left(\mathrm{C}(8)-\mathrm{CO}_{2} \mathrm{H}\right)$, $166.46\left(\mathrm{CH}_{2} \mathrm{CO}_{2} \mathrm{H}\right), 171.92$ (C-2), 176.76 (C-7); IR (NaCl): v 3417, 3373, 3333, 2917, 2724, 2662, 1730,1643, 1435, 1265, 1448, $1074 \mathrm{~cm}-1$; Anal. Calcd. for $\mathrm{C}_{16} \mathrm{H}_{14} \mathrm{FN}_{3} \mathrm{O}_{6}$ (363.08): C, 52.90; $\mathrm{H}, 3.88$; N, 11.57. Found: C, 52.45; H, 3.64; N, 11.18 .

\section{3-(Carboxymethyl)-5-fluoro-10-(4- fluorophenyl)-2,7-dioxo-1,2,3,4,7,10- hexahydropyrido [2,3-f] quinoxaline-8- carboxylic acid (compound 45)}

Yellow solid: yield $=0.37 \mathrm{~g}(38 \%) ; \mathrm{mp}=257-$ $262{ }^{\circ} \mathrm{C} ;{ }^{1} \mathrm{H}$ - NMR (300 MHz, DMSO- $\left.\mathrm{d}_{6}\right): \delta 2.72$ (br s ,2 H, CH $\left.2-\mathrm{CO}_{2} \mathrm{H}\right), 4.12(\mathrm{~m}, 1 \mathrm{H}, \mathrm{NH}-\mathrm{CH}-3)$, 7.40 - $7.46\left(\mathrm{~m}, 2 \mathrm{H}, \mathrm{H}-3^{\prime} / \mathrm{H}^{-5}\right), 7.53(\mathrm{NH}(4)), 7.75$ $\left(\mathrm{m}, 2 \mathrm{H}, \mathrm{H}-2^{\prime} / \mathrm{H}^{-} 6^{\prime}\right), 7.80\left(\mathrm{~d},{ }^{3} \mathrm{~J}_{\mathrm{H}-\mathrm{F}}=10.8 \mathrm{~Hz}, 1 \mathrm{H}\right.$, $\mathrm{H}-6), 8.54$ (s, $1 \mathrm{H}, \mathrm{H}-9), 10.68$ (brs, $1 \mathrm{H}$, $\mathrm{N}(1)-\mathrm{H}), 12.51$ (brs, $1 \mathrm{H}, \mathrm{CH}_{2}-\mathrm{COOH}$ ), 15.25 (s, 1 $\mathrm{H}, \mathrm{C}(8)-\mathrm{COOH}) ;{ }^{13} \mathrm{C}-\mathrm{NMR}(300 \mathrm{MHz}$, DMSO- d6 ): $\delta 37.23\left(\mathrm{CH}_{2}-\mathrm{CO}_{2} \mathrm{H}\right), 54.83(\mathrm{CH}-\mathrm{NH}), 109.65$ (C-8), 114.60 (C-6), 116.36 (C-4a), 117.16 (d, $\left.{ }^{2} J_{\mathrm{C}-\mathrm{F}}=22.2 \mathrm{~Hz}, \mathrm{C}-3^{\prime} / \mathrm{C}-5^{\prime}\right), 118.16\left(\mathrm{~d},{ }^{3} J_{\mathrm{C}-\mathrm{F}}=7.5\right.$ $\mathrm{Hz}, \mathrm{C}-6 \mathrm{a}), 127.7$ (C-10a), 128.62 (C-2'), 128.62 $\left(\mathrm{C}-6^{\prime}\right), 138.28\left(\mathrm{C}-1^{\prime}\right), 150.98\left(\mathrm{~d},{ }^{1} \mathrm{~J}_{\mathrm{C}-\mathrm{F}}=248.32\right.$ $\mathrm{Hz}, \mathrm{C}-5), 152.72$ (C-9), 162.38 (d, ${ }^{1} \mathrm{~J}_{\mathrm{C}-\mathrm{F}}=245.4$ $\left.\mathrm{Hz}, \mathrm{C}-4^{\prime}\right), 156.25$ (C-2), $172.46\left(\mathrm{C}(8)-\mathrm{CO}_{2} \mathrm{H}\right)$, $172.51\left(\mathrm{CH}_{2} \mathrm{CO}_{2} \mathrm{H}\right), 175.80$ (C-7); IR ( $\left.\mathrm{NaCl}\right)$ : v3417, 3373, 3333, 2917, 2750, 2350, 2300, 1730, 1650, 1448, $1074 \mathrm{~cm}^{-1}$.

\section{Inhibition of GSK-3 $\beta$ activity in vitro}

In vitro inhibitory activities of synthon II derivatives (compounds 6, 23 and 45) were tested against human recombinant GSK-3 $\beta$. Each compound was screened at an initial concentration of $10 \mathrm{nM}$. The results showed that inhibitory effect of compound $\mathbf{4 5}$ was better than those of compounds 6 and 23 (Table 1; Figure 4).

\section{Molecular modelling results}

The binding interactions of compound 45 with GSK-3 $\beta$ were determined using LibDock tool. The procedure revealed many interactions between compound $\mathbf{4 5}$ and the binding site of the enzyme (Figures 5 and 6). 
Table 1: Inhibition of GSK-3 $\beta$ by synthon II derivatives

\begin{tabular}{lcccc}
\hline Compound & $\begin{array}{c}\text { 1X Test compound } \\
\text { concentration }(\boldsymbol{\mu M})\end{array}$ & $\begin{array}{c}\text { [ATP] } \\
(\boldsymbol{\mu M})\end{array}$ & Inhibition (\%) & IC $\boldsymbol{5}_{\mathbf{5 0}}(\boldsymbol{\mu} \mathbf{M})$ \\
\hline $\mathbf{2 3}$ & 10 & $\mathrm{Km} \mathrm{app}$ & 31 & $\mathrm{NC}$ \\
$\mathbf{6}$ & 10 & $\mathrm{Km} \mathrm{app}$ & 94 & 2.01 \\
$\mathbf{4 5}$ & 10 & $\mathrm{Km} \mathrm{app}$ & 97 & 0.18 \\
\hline
\end{tabular}

NC: not calculated

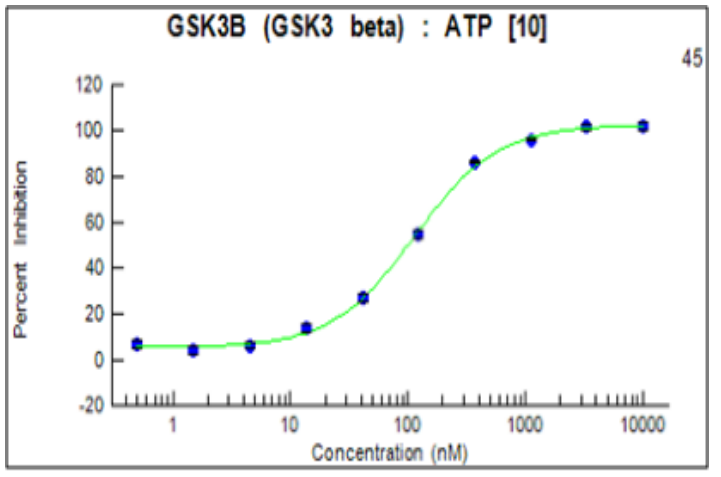

Figure 4: Inhibition of GSK-3 $\beta$ by compound 45

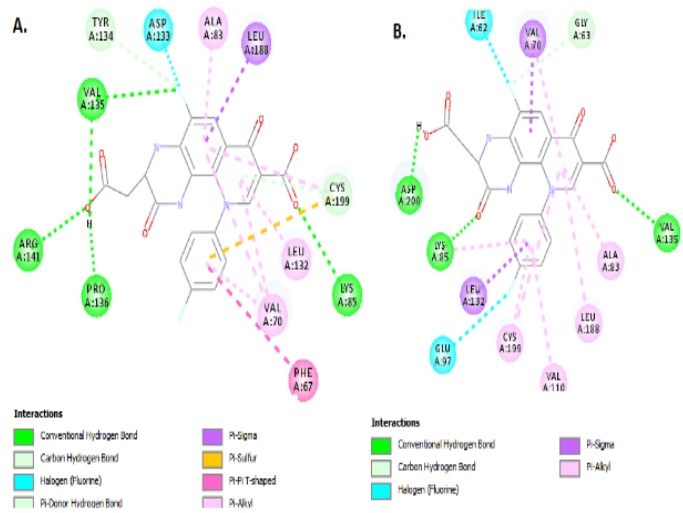

Figure 5: Two-dimensional representation of the interaction between compound 45 and GSK-3 $\beta$, showing two different poses ( $A$ and $B$ )
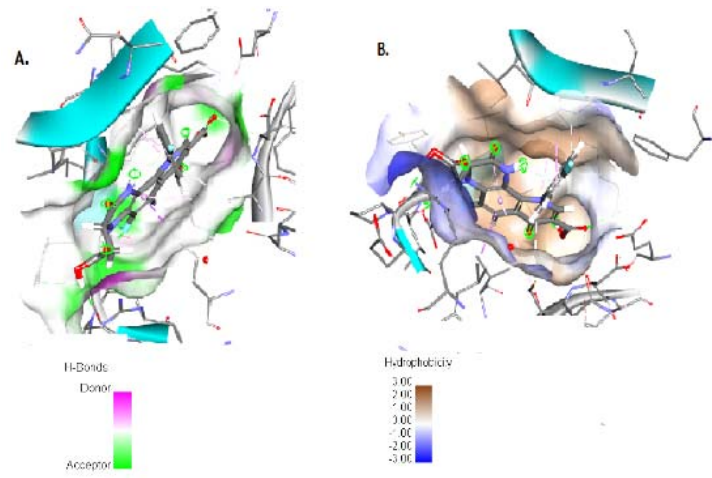

Figure 6: Interaction of compound 45 with binding site of GSK-3 $\beta$. (A): Hydrogen bonding between compound 45 and GSK-3 $\beta$; and (B): Hydrophobic interaction between compound $\mathbf{4 5}$ and GSK-3 $\beta$.

\section{DISCUSSION}

The need to find novel GSK-3 $\beta$ inhibitors is of great importance, since the enzyme is involved in many biological processes. In this study, many compounds were synthesized and tested against GSK-3 $\boldsymbol{\beta}$. The results of in vitro activity assay showed that compound $\mathbf{4 5}$ exhibited potent inhibitory activity against GSK-3 $\beta$. Molecular modelling revealed that compound $\mathbf{4 5}$ assumed different conformations inside the binding pocket of GSK-3ß. The quinoline nucleus exhibited remarkable interactions. It interacted with Leu 188 through sigma bond formation, and with Leu 132, Val 70 and Ala 83 via pi-alkyl interaction.

In other poses, the quinoline nucleus of compound $\mathbf{4 5}$ formed sigma bond with Val 70 , and pi-alkyl interaction with Ala 83 and Leu 188. In addition, the 8-carboxylic acid group formed hydrogen bond with Lys 85 and Val 135 in pose B. Fluorine atom at position 5 of compound 45 formed fluorine-hydrogen bond with Asp 133 and Ile 62, and with Val 135 in the other pose. The 10-(4-fluorophenyl) group in compound 45 formed sulfur-hydrogen bond with Val 70 and pialkyl (pi-pi) interaction with Phe 67, but it formed sigma bond with Leu 132 . The fluorine atom formed pi-alkyl bond with Cys 199 and Val 110, but interacted with Glu 97 via hydrogen bonding. The quinoxoline nucleus of compound 45 had 2oxo substitutions that formed hydrogen bond with Lys 85. The 3-(carboxymethyl) group of the compound was also involved in hydrogen bond formation with Arg 141, Pro 136, Val 135 and Asp200. Hydrogen bonds and hydrophobic interactions were also observed on surfaces of docked compound 45 and GSK-3 $\beta$. These results indicate that compound $\mathbf{4 5}$ may have interacted with the binding site of GSK-3 $\beta$ via hydrogen and hydrophobic bonds.

\section{CONCLUSION}

The results obtained in this study show that 3(carboxymethyl)-5-fluoro-10-(4-fluorophenyl)-2,7dioxo-1,2,3,4,7,10-hexahydropyrido $[2,3-f]$ quinoxaline-8-carboxylic acid is a potent inhibitor of GSK-3 $\beta$ and is thus, a promising scaffold for the development of novel drugs that can effectively inhibit GSK-3 $\beta$ signaling pathway. 


\section{DECLARATIONS}

\section{Acknowledgement}

Special thanks go to the Director of research and Dr Ahlam Alkilani, Dean of Faculty of Pharmacy, Zarqa University, Jordan, for their immense support and contribution to this work.

\section{Conflict of interest}

No conflict of interest is associated with this work.

\section{Contribution of authors}

We declare that this work was done by the authors named in this article and all liabilities pertaining to claims relating to the content of this article will be borne by the authors.

\section{Open Access}

This is an Open Access article that uses a funding model which does not charge readers or their institutions for access and distributed under the terms of the Creative Commons Attribution License (http://creativecommons.org/licenses/by/ 4.0) and the Budapest Open Access Initiative (http://www.budapestopenaccessinitiative.org/rea d), which permit unrestricted use, distribution, and reproduction in any medium, provided the original work is properly credited.

\section{REFERENCES}

1. Woodgett JR. Molecular cloning and expression of glycogen synthase kinase- 3/factor A. EMBO J. 1990; 9: 2431 - 2438.

2. Pandey MK, Degrado TR. Glycogen Synthase Kinase-3 (GSK-3)-Targeted Therapy and Imaging. Theranostics. 2016; 6 (4): 571 - 593.

3. Henriksen EJ, Dokken BB. Role of glycogen synthase kinase-3 in insulin resistance and type 2 diabetes. Curr Drug Targets. 2006; 7: 1435 - 1441.

4. Lee J, Kim MS. The role of GSK-3 in glucose homeostasis and the development of insulin resistance. Diabetes Res Clin Pract. 2007; 77 (Suppl 1): S49 - S57.

5. Martinez A, Gil C, Perez DI. Glycogen synthase kinase 3 inhibitors in the next horizon for Alzheimer's disease treatment. Int J Alzheimers Dis. 2011; 280502.

6. Luo J. Glycogen synthase kinase 3beta (GSK3 beta) in tumorigenesis and cancer chemotherapy. Cancer Lett. 2009; 273 (2): 194 - 200.

7. Zhou W, Wang L, Gou Sh, Wang T, Zhang M, Liu T, Wang Ch. ShRNA silencing glycogen synthase kinase-3 beta inhibits tumor growth and angiogenesis in pancreatic cancer. Cancer Lett. 2009; 316 (2): 178 186.

8. Farago $M$, Dominguez I, Landesman-Bollag $E$, $X u X$, Rosner A, Cardiff RD, Seldin DC. Kinase-inactive glycogen synthase kinase 3beta promotes Wnt signaling and mammary tumorigenesis. Cancer Res. 2005; 65: 5792 - 5801.

9. Roesner M, Billhardt-Troughton UM, Kisch R, Kleim JP, Meichsner C, Riess G, Winkler I. Preparation of quinoxalinones as antiviral agents. Eur Pat Appl. 1996; 708093: 30.

10. Seto S, Yumoto K, Okada K, Asahina Y, Iwane A, Iwago $M$, Terasawa $R$, Shreder KR, Murakami K, KohnoY. Quinolone derivatives containing strained spirocycle as orally active glycogen synthase kinase $3 \beta$ (GSK-3 $\beta$ ) inhibitors for type 2 diabetics. Bioorg Med Chem. 2012; 20 (3): 1188 - 1200.

11. Tariq S, Somakala K, Amir M. Quinoxaline: An insight into the recent pharmacological advances. Eur J Med Chem. 2018; 143: 542 - 557.

12. Lunniss CJ, Cooper AW, Eldred CD, Kranz M, Lindvall M, Lucas FS, Neu M, Preston AG, Ranshaw LE, Redgrave $A J$, et al. Quinolines as a novel structural class of potent and selective PDE4 inhibitors: Optimisation for oral administration. Bio Med Chem Letters. 2009; 19 (5): 1380 - 1385.

13. Swellmeen L, Shahin R, Al-Hiari Y, Alamiri A, Hasan A, Shaheen $O$. Structure based drug design of Pim-1 kinase followed by pharmacophore guided synthesis of quinolone-based inhibitors. Bio Med Chem. 2017; 25 (17): $4855-4875$.

14. Cociorva OM, Li B, Nomanbhoy T, Li Q, Nakamura A, Nakamura K, Nomura M, Okada K, Seto S, Yumoto K, et al. Synthesis and structure-activity relationship of 4quinolone-3-carboxylic acid-based inhibitors of glycogen synthase kinase-3b. Bio Med Chem Letters. 2011; 21 (19): 5948 - 5951.

15. Arfeen M, Bharatam PV. Design of Glycogen Synthase Kinase-3 Inhibitors: An Overview on Recent Advancements. Curr Pharma Design. 2013; 19 (26): 4755 - 4775.

16. Select Screen TM Biochemical Kinase Profiling Service, Z'-LYTETM Screening Protocol and Assay Conditions, 2016 (USA). https://www.thermofisher.com/jo/en/ home/products-and-services/services/customservices/screening-and-profiling-services/selectscreenprofiling-service/selectscreen-kinase-profilingservice.html.

17. Al-Hiari YM, Qaisi AM, AbuShuheil MY, El-Abadelah MM, Voelter $W$. Synthesis and antibacterial potency of 4methyl-2,7-dioxo-1,2,3,4,7,10-hexahydropyrido[2,3-f]quinoxaline-8 carboxylic acid, selected [a]-fused heterocycles and acyclic precursors. Chemical Sci. 2007; 62B: 1453 - 1458. 